\title{
Decision Support System Module for Sustainable Land Development for Thailand: A Case of Chonburi Province
}

\author{
Pisase Senawongse $e^{1} \&$ Apisit Eiumnoh ${ }^{2}$ \\ ${ }^{1}$ Faculty of Geoinformation, Bhurapha University, Chonburi province, Thailand and Tesco Ltd. Bangkok, \\ Thailand \\ ${ }^{2}$ National Center for Genetic Engineering and Biotechnology, National Science and Technology Development \\ Agency, Pathumthani, Thailand \\ Correspondence: Pisase Senawongse, Faculty of Geoinformation, Bhurapha University, Chonburi province, \\ Thailand and Tesco Ltd. Bangkok, Thailand. Tel: 6681-8092261. E-mail: senawongse1500@hotmail.com
}

Received: March 11, 2019

Accepted: April 23, $2019 \quad$ Online Published: May 30, 2019

doi:10.5539/jsd.v12n3p159

URL: https://doi.org/10.5539/jsd.v12n3p159

\begin{abstract}
A decision support system (DSS) module for sustainable land development for Thailand: A case of Chonburi province was developed for decision makers based on available geographic information databases and overlaying techniques available on an internet network. Chonburi province in the Southeast Coast of Thailand was assigned as a special economic development zone or Eastern Economic Corridor (EEC) is a fast growing area for industrial and infrastructure developments causing land use conflicts between privates and governments that were observed elsewhere. Databases including administrative boundary, land resources, land uses, national policies and legislation aspects were integrated for land suitability, condition and limitation for land developments. The system employed ArcGIS Geo-processing service module available on the Central Relation Database that can be accessed via Web Services and RSS. The decision makers could access from the Web Browser and make decision under three conditions, by screening areas for specific land use types, analyzing land use limitations and conditions or for maximum land use benefits. The developed DSS module on land resources spatial analysis and legislation limitations would be a simple technological tool to preliminary and fast selection of proper land managements in the future and would be able to apply in other parts of the country.
\end{abstract}

Keywords: decision support system, module, sustainable land development, Thailand, Chonburi province

\section{Introduction}

\subsection{Introduce the Problem}

Thailand has long been as an agricultural based country, while industrials and tourism businesses have recently become main incomes of the country. The previous Eastern Seaboard project has been established and implemented along the East coast in the Gulf of Thailand for few decades. The recently proposed Eastern Economic Corridor (EEC) plan consisted of three provinces, Chonburi province is among the other two provinces namely Chachoengsao and Rayong provinces (Figure 1). These provinces have similar land resource types, mainly topography, soils, agricultures, land use types, protected forests, residential and rural, and surface water areas. The EEC development goal was devoted to improve industrial economy of the country would require large areas for factory, warehouse, infrastructure and utility developments. Large projects on transportation including deep seaport, airport, highway, railway and high speed train were proposed (Ministry of Industry, 2017). 


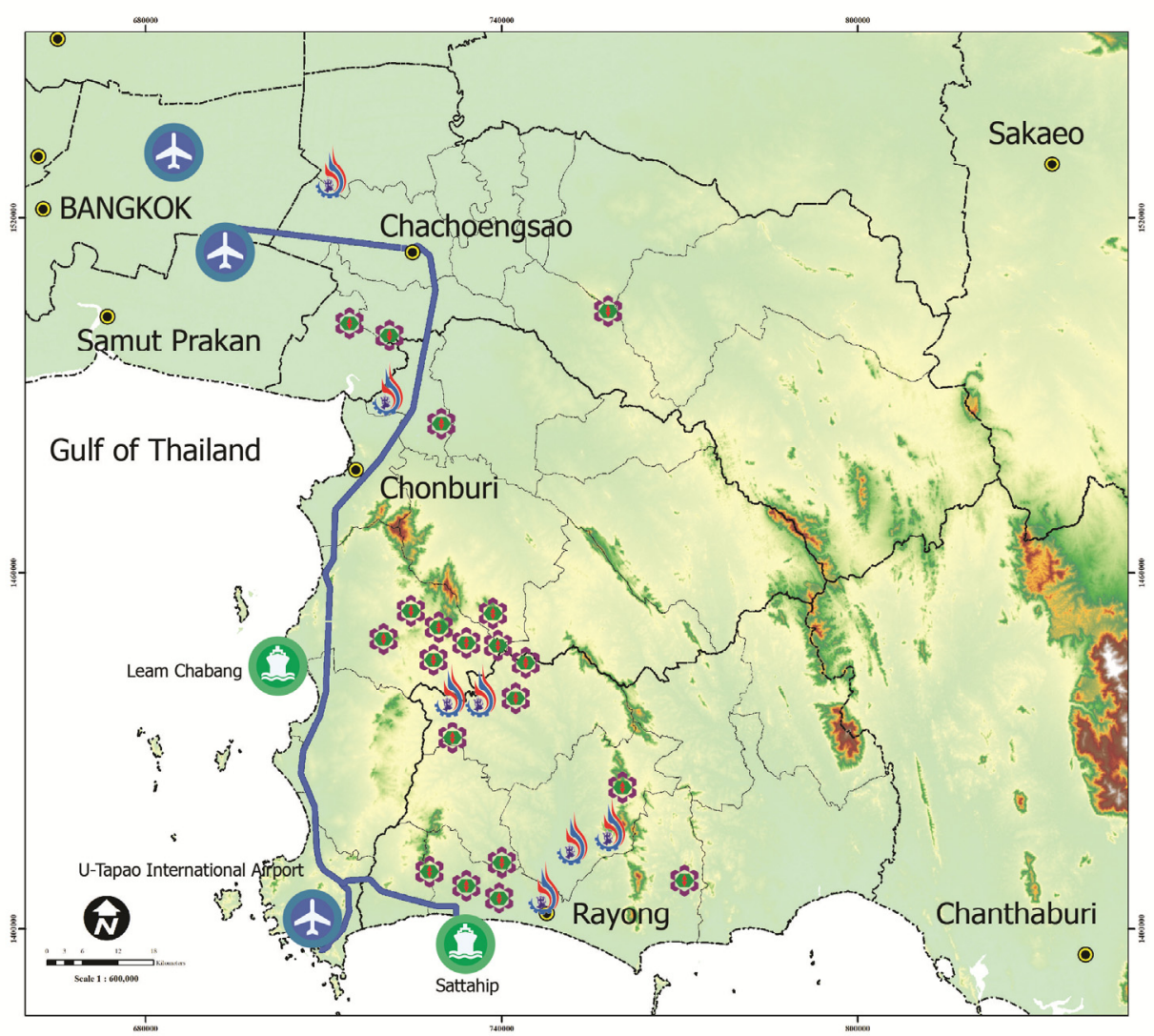

legend

2 Deep seaport

(1) Airports

8 Industrial Estate

4) Industrial Parks

High speed train

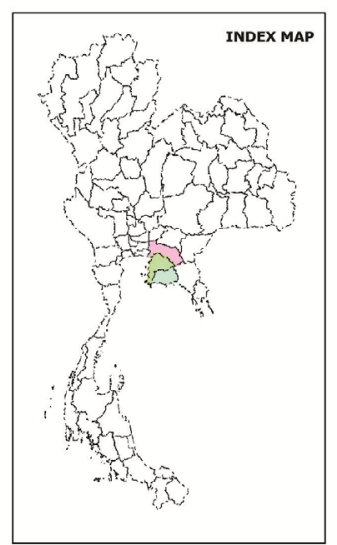

Figure 1. Map of Chachoengsao, Chonburi and Rayong provinces in the Eastern Economic Corridor (EEC) plan of Thailand

There were existing problems on land resource managements at both policy levels and implementing agencies due to no practical and simple management framework and replication of duties and works. Though geographical databases were available in most government agencies, there were lack of data manipulation, integration and management to increase efficiency for land applications. Several satellite remotely sensed data were available to update land cover and land use types and changes. The geographic information system (GIS) has been employed for land resource managements, but difficult to access for site specific and data and information improvements. The available GIS data of land resources at various scales, mapping unit and map projection were difficulty for land resources analyses. The legislation aspects including laws, regulations, limitations and conditions of lands under different government offices were difficult to access and to be integrated into the required analyses. In addition, there were many land degradations and land use problems that 
related to legal, regulations, measures and ministerial agreements. There were also uncleared boundary between governments, reserved forests and private owned lands. Therefore, land right and land use conflicts and debates were often occurred between government and private sectors when a piece of land was proposed for development (Office of Natural Resources and Environmental Policy and Planning, 2015). The availability and capability of an online Web service has made the GIS database analyses simple, fast and accurate for decision makers and concerned interested sectors.

\subsection{Importance of the Problem}

Land degradation was defined as a long term loss of ecosystem functions over time, as perceived by the land users (FAO, 2013). Land degradations, soils and water deteriorations and decreasing of forested lands have impacted to global climate change and food insecurity. Degradations of agricultural lands caused crop yield reductions and economic losses, hence caused expansion of land for livings into marginal areas for more crop productions by poor farmers. Land degradations have been major constraints on land development in Thailand. Thailand located in Southeast Asia has a total land area of 51.3 million ha. The Land Development Department (2010) reported that in 1995 land degradations were 70.13\% (36 million ha) of the country area and have been gradually increasing yearly. The main land degradation types were soil degradation including soil erosion, $41.95 \%$ and soil nutrient imbalance, $8.32 \%$ of the country area. In addition there were $17.44 \%$ of inherent problem soils distributed in the country.

Thailand Environment Institute (2018) reported that river water quality in the East of the country still had moderate condition, except the poor BOD in areas closed to main cities. Along the coast, seawater was in good condition and had potential for improvement. However, expansion of urban, resort and recreation areas into good agricultural lands and upstream watersheds were rapidly increasing without direction. Industrial estates and public infrastructures and utilities were not well prepared.

The Office of Natural Resources and Environmental Policy and Planning (2018) identified many land use problems in the country including encroachment of protected and forested lands and reserved government lands, unsuitable land use for crop production and settlements, land boundary conflicts, replication of land licenses, lack of strict law enforcements for natural resources protection, lack of law enforcements of city plans and urbanizations, unequal land distributions among the poor and the rich people, insufficient land areas for livings and many abandoned lands. There were also many problems on land use policies and managements.

In order to reduce land and environmental degradations, the governments have issued legislations and measures and have been implementing for sustainable management of natural resources and environments. The Ministry of Natural Resources and Environment has issued amendments of the Enhancement and Conservation of National Environmental Quality Act, B.E. 2535 (1992) to strictly require environmental impact assessment (EIA) and health impact assessment (HIA) for many industrials and land development projects in the country. (Ministry of Natural Resources and Environment, 2019). The amendment and guideline were disseminated and available to publics.

\subsection{Thailand and Sustainable Development Goals}

In 2017 the major land use types in Thailand were $47 \%$ agriculture, $32 \%$ forested and $21 \%$ non-agricultural lands respectively (Office of Natural Resources and Environmental Policy and Planning, 2017). But in 2015 the agricultural and forested lands were $55.40 \%$ and $33.00 \%$ respectively. (Department of Land Development, 2018a). It was found that the community and settlement, industrial estate and water body areas were increasing as compared between the two periods. Thailand has introduced the Sustainable Development Goals (SDG) and the United Nations Convention to Combat Desertification (UNCCD) concepts for land degradation corrections and managements since their initial launched. The Department of Land Development has been responsible on the SGD Goal 15.3 on combating and restore degraded land and soil, including drought and floods in the country. (Land Development Department, 2018b). In order to reduce impacts and promote climate change adaptations of land degradations, policies, mitigation plans and measures were developed (Office of Natural Resources and Environmental Policy and Planning, 2014). The climate change adaptations was focused on preparation and development of basic infrastructure and driving mechanisms at policy levels in the short term period (20182021). The medium term (2021- 2026) was on the operation mechanisms and building capacity for climate change adaptation and the long term period (2027-2057) would be a continuation of the medium term (Office of Natural Resources and Environmental Policy and Planning, 2019). The 20 years National Forest Strategy has policy to increase forested areas to $40 \%$ of the country area (Department of National Parks, Wildlife and Plants, 2018). The SDGs including people, planet, prosperity, peace and partnership could not be achieved without active implementations of all stakeholders at all levels (Japan Ministry of Foreign Affairs, 2015). Land allocation 
policy has currently been implemented for poor and landless people.

Thailand submitted the SGDs under the Second Voluntary National Review to the UN Headquarters in 2017 (Ministry of Foreign Affairs, 2018). But the SDG Goal 15 was emphasized on sustainable forest management by proposing $40 \%$ forest cover in the country by 2020 . In addition, Thailand has launched the 20 -Year National Strategy Framework (2017-2036) for the whole country following the Principle of Sufficiency Economy Philosophy of His Majesty the Late King Bhumibol Adulyadej. The developed framework has six areas namely security, competitiveness enhancement, human capacity development, social equality, eco-friendly growth, and rebalancing and improving public sector managements. The Office of the National Economic and Social Development Board (NESDB) was a leader in developing SDG indicators that were incorporated into the past and the current National Economic and Social Development Plans. The SDG has included implementing agencies at all levels from ministerial to provincial and local administrative.

In order to implement and accelerate the SDG, FAO (2018) proposed five principles with 20 actions that were interconnected for decision makers. Particular to natural resources and land degradations, few actions were established. Action 5 was on enhance soil health and restore land as soils were degraded due to unsuitable managements and action 16 was suggested to strengthen ecosystem resilience by trading-offs the existing between ecosystem resilience and agriculture intensification. The policy support tools including data and experience and draft by multiple stakeholders were suggested.

Land resources databases, geology, soil, land utilization, land suitability and administrative boundary were employed for land use zoning between urban and rural areas. Analysis of high resolution satellite imagery and field work were commenced for field verification (Punya P. Oli, 2018). Gergely, T., T. Hermann, M.R. da Silva \& L. Montanarella (2018) (2018) suggested that soil properties, including soil hydraulic, nutrient and biodiversity were important to achieve SDG, particularly the SDG 15.

\subsection{Study area and Objectives}

The Chonburi province study area, 436,300 ha is located in the Southeast Coast of Thailand. The province is approximately 80 kilometers away from Bangkok. The vision of the province was industrial economy bases of Asian, international coastal tourism, safe agricultural products, gateways to world economics, learning society and sustainable natural resources developments. Topographically the province composes of mountains and steep slopes in the central and in the east, undulating topography in the north and south, and flat coastal plain in the west and south. There are 46 islands and islets in the west and south of the province. In 2016 the main land use types (Table 1) were agriculture, aquaculture and livestock consisting of $59.72 \%$ of the province area. Agricultural and tree crops on undulating topography were dominated by para-rubber, oil palm and fruit orchard. The upland field crops were sugarcane and cassava plantations. Fast growing trees and forest plantations were found in the agricultural lands. Lowland rice occupied small areas in depressions. The primary and secondary forested areas confined to hills and mountains were only $11.14 \%$ of the province area. The community, city and government offices and industrial estate areas were $15.08 \%$ and $4.31 \%$ of the province respectively. The surface water areas were only $2.28 \%$. Other land use types were roads and barren lands (Chonburi Province Office of Natural Resources and Environmental Policy and Planning, 2016). The distribution map of major land use types in Chonburi province were shown in Figure 2.

Table 1 Major land use types in Chonburi province in 2016

\begin{tabular}{|c|c|c|}
\hline Major Land Use Type & Area $(\mathrm{Ha})$ & $\%$ \\
\hline Agriculture, aquaculture and livestock & 260,572 & 59.72 \\
\hline Forest/mangrove forest & 48,625 & 11.14 \\
\hline Community and City & 65,807 & 15.08 \\
\hline Industrial & 18,822 & 4.31 \\
\hline Surface water & 9,953 & 2.28 \\
\hline Other & 32,521 & 9.23 \\
\hline Total & 436,300 & 100.00 \\
\hline
\end{tabular}

Source: Chonburi Province Office of Natural Resources and Environmental Policy and Planning, 2016 


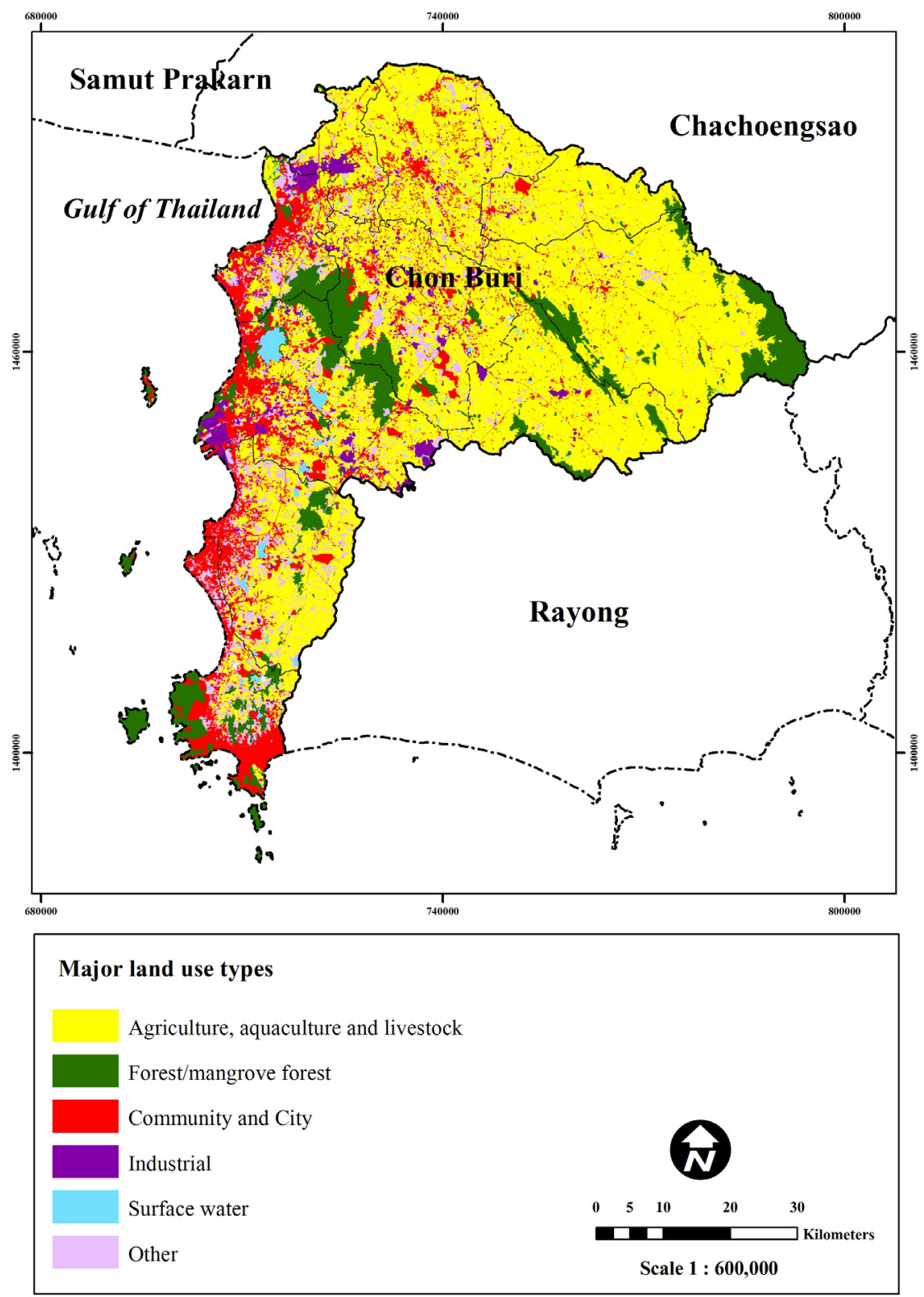

Figure 2. Distribution map of major land use types of Chonburi province in 2016

In 2011 the agricultural and forest land utilizations in Chonburi province were $62.12 \%$ and $11.02 \%$ respectively, indicating slightly decreasing of agriculture and increasing of forested areas as compared to the 2016 (Office of Agricultural Economics, 2012). This might indicate that agricultural lands were converted into other land uses as high demand of lands for industrial estates and residential developments were also increasing. In the past soil degradations were severe due to agricultural land expansion and improper cassava plantation and managements. Water shortages were also major constraints for agriculture, industrial and settlement developments as the amount of rainfalls were erratic and poorly distributed and no suitable area for water resource development. The province has already two deep seaports and many industrial estates and settlements. Urbanization has gradually increasing as the demands by industrial staff and labors migration.

The highly demands of lands for EEC development plans and the conservation of forested and good agricultural areas had increasing land use conflicts among users, governments, private sectors and publics. The EEC plans have been proposed and strongly supported by the government, while the environmentalists and conservationists were much concerned on proper the land resource managements that might cause adverse environmental impacts. 
Therefore the objective of this study was to develop a simple GIS web-based program for decision makers for sustainable land resources management in Chonburi province as a case study by collecting, improving and manipulating the existing official spatial and non-spatial databases and regrouping and analyzing them based on the online Web GIS.

\section{Method}

The spatial and non-spatial databases of Chonburi province were identified, collected and selected from concerned government offices. The secondary spatial databases were adjusted to the World Geodetic System 84 datum (WGS84) that would be fitted well to the Web GIS program. The data structure and topology were improved and verified. The related information obtained from various technical documents was interfaced to the system. All spatial and non-spatial databases were, then reorganized into three sets for management conveniences. Field surveys and observations were conducted for map and information validations. The program on the internet network was employed to manipulate and analyze for potential uses of lands by overlaying and integrating spatial and attribute data, conditions, limitations, legislations, regulations and technical managements. The program would increase the efficiency and speed up the decision on land managements in the province. This simple DSS tool available online could be accessed by land decision makers and interesting organizations for policy development or decision making on sustainable land resources managements, limitations and conditions.

\subsection{Databases}

All the spatial and non-spatial databases and reports obtained from the concerned government offices were divided into three data sets including (1) spatial baseline databases, (2) spatial resource databases for analysis and (3) non-spatial and spatial databases for condition and limitation analyses. The spatial baseline data were administrative boundary of the province, municipal, districts and sub-districts polygons and locations of the city. Other data were elevation above mean sea level, land transportations, water resources, villages and communities and sensitive locations. The spatial resource databases and attributes for analyses were soil series groups, soil series, soil suitability, land use types, conserved forests, national parks, digital elevation model and agricultural land reformed. The non-spatial and spatial databases for condition and limitation analyses were laws and regulations, related policies, city planning maps and regulations, environmental protected area maps, building controls, watershed classes maps and measures, economic crop nutrient requirements, soil suitability for economic crops, soil and water conservation recommendations for agricultural lands, environmental protection zone maps and measures and mitigations requirements on environmental impact assessment.

\subsection{Methodology}

The DSS module for sustainable land management consisted of a set of databases and commands that work on the internet Web GIS network. The module applied GIS overlaying techniques to cover all variables that were stable or changes with time based on satellite temporal imagery that would support to select most suitable areas for land development according to the available spatial databases. The databases were reorganized into the three data sets under the GIS structure and format and would be analyzed under three conditions.

The spatial baseline databases and attributes and their general information were used as an area of interest (AOI) at province, districts or sub-districts or Tambon levels or at any specific interested project area. The province, districts and sub-districts areas were obtained from the existing administrative polygon boundaries. The AOI at any size and anywhere in the province could be drawn directly from the developed systems.

The spatial resource databases were used for land resource managements. The decision analyses were based on conditions and limitations of land use types, land use types in the conserved and protected areas based on sustainable land managements, and for alternative land managements for maximum crop production and benefit. The non-spatial and spatial databases for condition analyses, such as the conserved forests and national parks, watershed class 1 and 2 maps and environmental protected areas were used as prohibited lands or uses with very special cautions. The agricultural land reformed maps were used as land utilizations only for agricultural purposes, as specified or limited by legislations. The soil maps and attributes were used as soil characterizations and suitability for common economic crops in the area, such as sugarcane, cassava, para-rubber and oil palm plantations. The slope map and the digital elevation model were employed to identify areas with slope more than $35 \%$ that limited for agriculture, but only for upstream watershed and forest covers. Recommendations for land reclamation and crop land improvements of specified areas (AOI) were suggested for decision makers.

The information related to legislations, regulations and policies and the concerned spatial databases were used as land development conditions and limitations that specific to the province such as solid-waste disposal sites and wastewater treatment plants. The conditions of conserved zones, laws and regulations, related policies on land 
development and city and project plans were required for sustainable land developments.

The environmental protected areas and measures were used to control the distant and height of buildings away from beaches and sensitive sites. The EEC proposed areas for industrial estates and settlements were used as high potential economic land developments.

The DSS module was developed on Geo-processing service under ArcGIS for server that installed on the "Application" that is provided as Web Service and RSS. Users could access via Web Brower, URL http://www.slum-chon.org/ or temporary at http://119.59.123.166/SlumChon/.

The methodology flow diagram was illustrated in Figure 3.

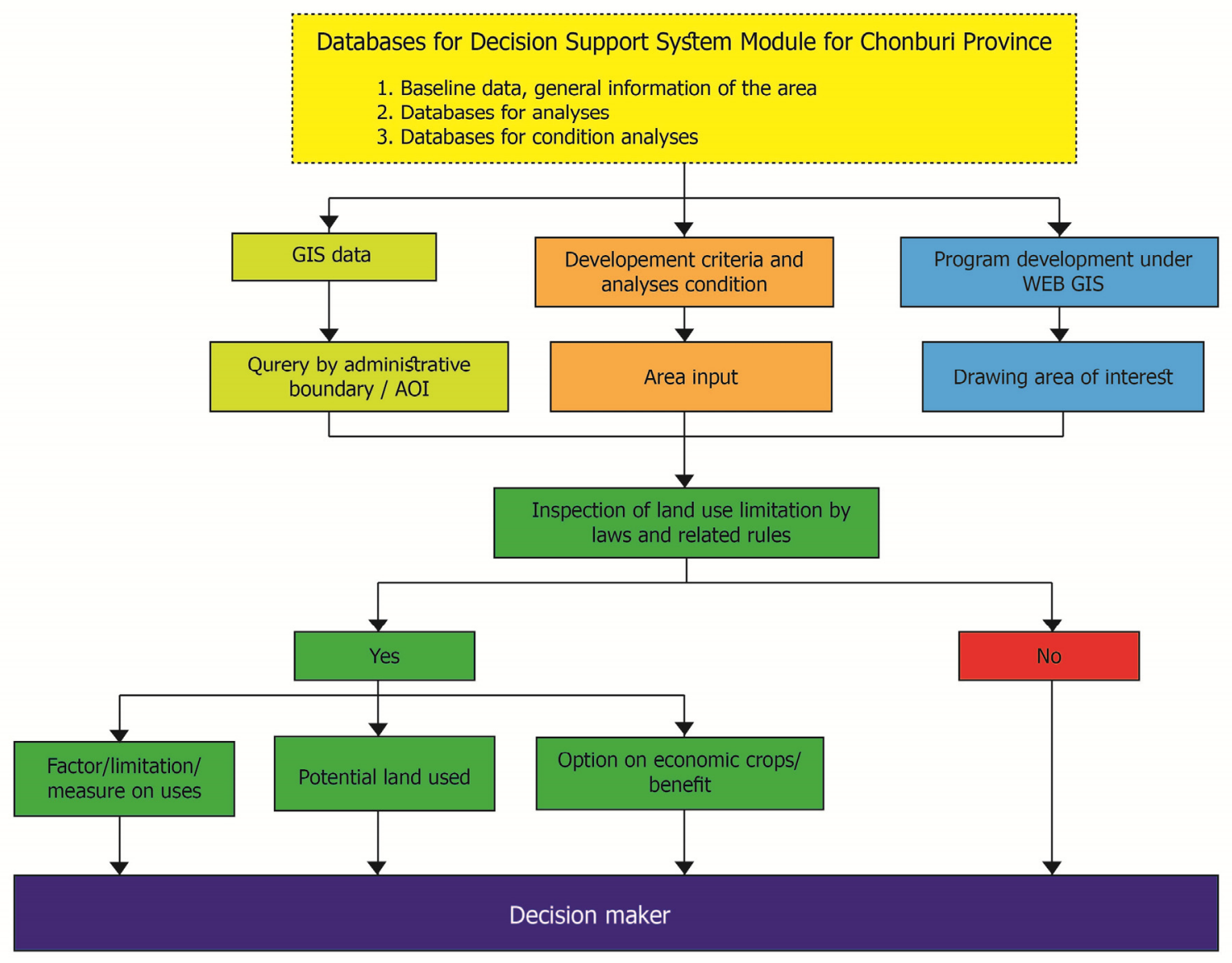

Figure 3. The methodology flow diagram of this study

\section{Results}

The developed DSS module for sustainable land development using spatial and non-spatial databases could be managed under three conditions, by screening areas for specific land uses, analyzing land use conditions and limitations or for maximum land use benefits.

The screening areas for specific land uses were obtained when an AOI was first selected before an overlaying the land use limitations such as the conserved forest map, national park map, watershed class 1 and 2 maps and land use conditions and limitations, prohibited land uses under agricultural land reformed policy, legislations and regulations and building height control or other land use prohibitions. Under this process the decision makers or interested sectors could draw an AOI for their own project by using draw area menu.

The land use limitations and conditions analyses were developed for decision making on suitable land uses although the areas might not have any prohibition, but might have limits to certain activities in the areas. The analysis began from selection of an AOI, followed by attributes of legislations, regulations and measures of the city plan, measures on building construction, measures of watershed classes, topography and slope, present land 
uses, transportations, waterways and utilities within the proposed areas. The suitable selected areas would be brought to land use potential for the particular development.

The maximum land use benefits were developed mainly for selection of suitable areas for common economic crops. The AOI was first identified, then followed by soil suitability parameters and water and crop requirements and managements, and area and yield of the proposed economic crops. The suitable, moderately suitable and non-suitable areas and crop types would be identified. The decision would be commenced from selection option of each economic crop that would provide the most benefit from the areas.

This first developed module was sent to some specialists to review and evaluate, and positive results were obtained. It hoped that this module would be an alternative tool for decision makers in the future.

\section{Discussion}

The DSS module for sustainable land development in Chonburi province was developed using GIS interactive techniques by integrating of selected layers from the three data sets of the improved databases, namely spatial baseline databases, spatial resource databases for analyses and information or non-spatial and spatial databases for condition analyses. The spatial databases from various governments were converted to the WGS 84 datum that fitted well with the GIS Web based. The condition analyses included screening of areas for specific land uses, land use conditions and limitations analyses and the maximum land use benefits. The module was developed on the Web GIS and RSS of ArcGIS Software that analyzed fast and smoothly on the internet network that can be easily accessed by decision makers. Though this module was in its initial stage, it can be used or modified by decision makers prior to any decision actions. Field checks and concerned stakeholder consultations were still required to validate the proposed AOI before the final decisions would be made. In order to apply to other provinces or area of interest in the Eastern region, the new similar database structures should be created.

\section{Acknowledgments}

The authors thank to Dr. Suphan Kanchanasutham and Associate Professor Dr. Kaew Nualchawee who continuously contributed and suggested valuable databases and analyses techniques. The authors also wished to thanks to concerned government offices that provided the GIS data and reports for this study. The authors also thank and highly appreciated to experts who reviewed and suggested for understanding and improving of the module efficiencies, especially to Ms. Janyaporn Klinbhuppha from the Department of Environmental Quality Promotion, Dr. Piyakarn Tiathisarp from Mahidol University, Dr. Uma Siboonruang from King Mongkut's Institute of Technology Ladkrabang and Mr. Kamron Trifuk from the Department of Land Development.

\section{References}

Chonburi Province Office of Natural Resources and Environmental Policy and Planning. (2016). Monitoring report on assessment of action plans on environmental quality management. Office of Natural Resources and Environmental Policy and Planning, Chonburi province.

Department of National Parks, Wildlife and Plants. (2018). 20 Years strategy on national parks, wildlife and plants (B.E. 2560 - 2579) (Draft). Department of National Parks, Wildlife and Plants, Ministry of Natural Resources and Environment.

FAO. (2013). Land degradation assessment in dry-lands: Mapping land use systems at global and regional scales for land degradation assessment analysis, Version 1.1. Food and Agriculture Organization of the United Nations, Rome.

FAO. (2018). Transforming food and agriculture to achieve the SGDs. Food and Agriculture Organization of the United Nations, Rome.

Gergely, T., Hermann, T., da Silva, M. R., \& Montanarella, L. (2018). Monitoring soil for sustainable development and land degradation neutrality. Environ Monit Assess, 190(57). https://doi.org/10.1007/s10661-017-6415-3

Japan Ministry of Foreign Affairs. (2015). White paper on development cooperation 2015, Chapter 2 the 2030 agenda for sustainable development, Section 1 Efforts leading up to the 2030 agenda for sustainable development. Japan Ministry of Foreign Affairs.

Land Development Department. (2010). Land degradation and amendment. Land Development Department, Ministry of Agriculture and Cooperatives.

Land Development Department. (2018a). Conclusion on land use of Thailand (B.E. 2543/2544, 2549/2550, 2551/2552, 2553/2556, 2558/2559). Retrieved October 10, 2018, from 
http://www.ldd.go.th/www/lek_web/web.jsp?id=18671

Land Development Department. (2018b). UNCCD National Action Plan 2015- 2018 (Draft). Land Development Department, Ministry of Agriculture and Cooperatives.

Ministry of Foreign Affairs. (2018). Thailand's Voluntary National Review on the Implementation of the 2030 Agenda for Sustainable Development. Minister of Foreign Affairs of the Kingdom of Thailand.

Ministry of Industry. (2017). Eastern economic corridor development project: Driving forward. Ministry of Industry.

Ministry of Natural Resources and Environment. (2019). Thai Act on 4 January 2019, Projects, activities or operations that might have severe impacts to quality of natural resources, sanitary, health and lifestyle of communities. Ministry of Natural Resources and Environment.

Office of Agricultural Economics. (2012). Agricultural Statistics of Thailand 2012. Office of Agricultural Economics. Ministry of Agricultural and Cooperatives.

Office of Natural Resources and Environmental Policy and Planning. (2014). Project on policy driven, plans and measures to manage lands to cope with climate change, Final Report. Office of Natural Resources and Environmental Policy and Planning, Ministry of Natural Resources and Environment.

Office of Natural Resources and Environmental Policy and Planning. (2015). Integrated master plan for management of biological diversity, 2015-2021. Office of Natural Resources and Environmental Policy and Planning, Ministry of Natural Resources and Environment.

Office of Natural Resources and Environmental Policy and Planning. (2017). Second Biennial Update Report of Thailand. Office of Natural Resources and Environmental Policy and Planning, Ministry of Natural Resources and Environment.

Office of Natural Resources and Environmental Policy and Planning. (2018). National land and soil resources management plan (2017- 2021), enhancing the period. Office of Natural Resources and Environmental Policy and Planning, Ministry of Natural Resources and Environment.

Office of Natural Resources and Environmental Policy and Planning. (2019). Second Thaialnd national adaptation plan. Office of Natural Resources and Environmental Policy and Planning, Ministry of Natural Resources and Environment.

Punya P. Oli. (2018). Land Use Zoning towards the fulfillment of the 2030 Agenda for Sustainable Development (9273). International Federation of Surveyors (FIG) Congress 2018: Embracing our smart world where the continents connect: enhancing the geospatial maturity of societies. Istanbul, Turkey, May 6-11, 2018.

Thailand Environment Institute. (2018). Report on environmental quality status. Thailand Environment Institute. (Distributed to obtain suggestion from Publics on 18 July B.E. 2561 at Mayfair Ballroom of the Berkley Hotel, in Bangkok, Thailand).

\section{Copyrights}

Copyright for this article is retained by the author(s), with first publication rights granted to the journal.

This is an open-access article distributed under the terms and conditions of the Creative Commons Attribution license (http://creativecommons.org/licenses/by/4.0/). 